\title{
À RODA DA VIDA DE MACHADO DE ASSIS EM "VIAGENS E VIAJANTES NA HISTÓRIADA LITERATURA"
}

\author{
The wheel of life of Machado de Assis in the short story "Viagens e Viajantes na \\ História da Literatura"
}

\author{
Milena Alves Borba \\ https://orcid.org/0000-0002-1368-2923 \\ Universidade Federal de Pelotas, Programa de Pós-graduação em Letras, Pelotas, RS, Brasil. \\ 96010-610-ppgl.ufpel@gmail.com

\section{Alfeu Sparemberger} \\ https://orcid.org/0000-0001-6003-6353 \\ Universidade Federal de Pelotas, Centro de Letras e Comunicação, Pelotas, RS, Brasil. \\ 96010-610-ascomclc@gmail.com
}

Resumo: O presente trabalho é o resultado de uma análise transtextual, conforme dispõe Genette (2006), do conto "Viagens e Viajantes na História da Literatura", de João Inácio Padilha (1988). Tal análise é aliada à concepção da dupla estrutura formal do conto, de Ricardo Piglia (2004), aos preceitos da metaficção historiográfica, de Hutcheon (1989), e aos de ficção autobiográfica, de Perrone-Moisés (2016). Esta análise, típica das práticas hipertextuais, permitirá observar como o conto objeto retoma enunciados primeiros para ressignificá-los e recontextualizá-los na construção da sua narrativa. Verificando-se que "Viagens e viajantes na História da Literatura" resulta em uma poética da escrita machadiana que permite repensar a obra do autor de Dom Casmurro como uma narrativa de resistência aos grandes centros hegemônicos, como é o caso da França, para a época do escritor. Machado propunha um encontro dialético entre o que seria uma escrita nacional e universal, negando a obrigatoriedade de uma escrita exótica de cor local para anular a fronteira entre o local e o universal.

Palavras-chave: João Inácio Padilha. Machado de Assis. Paródia. Metatextualidade.

Abstract: This paper is the result of a transtextual analysis, as discussed by Ginette (2006), of the short story "Viagem e Viajantes na História da Literatura" (1988), by João Inácio Padilha. To help with the analysis, other concepts were also used: the concept of the dual formal structure of short stories, by Ricardo Piglia (2006); the precepts of historiographic metafiction, by Hutcheon (1989); and the concept of autobiographical fiction, by Perrone-Moisés (2016). This analysis, typical of the hipertextual practice, allows us to observe how the short story retakes original statements to resignify and recontextualize them during the construction of its 
narrative.In this process, the short story by João Padilha shows, indirectly, the way the readers should read the story because it activates references that work as reading metaphors, as a way of going through Machado de Assis's work/text through the principle of palimpsestic construction. Through this reading operation, the reader is invited to be a traveler, but she/he should, therefore, activate a determinate reading repertoire which equals to moving through a vast series of literary traditions.

Keywords: João Inácio Padilha. Machado de Assis. Parody. Metatextuality

\section{Introdução}

Este trabalho apresenta uma análise transtextualdo conto Viagens e viajantes na história da literatura (1988), de João Inácio Padilha. Tal análise, típica das práticas hipertextuais, no sentido abrangente da terminologia genettiana, que "coloca [o texto] em relação, manifesta ou secreta, com outros textos" (GENETTE, 2006, p. 7), permite observar como o conto objeto retoma enunciados primeiros para ressignificá-los e recontextualizá-los, atuando de modo determinante na construção narrativa. Para isso, procede-se a uma leitura vertical, pois, como adverte Samoyault (2008), a prática hipertextual torna-se presente de maneira vertical, já que esta é a forma de impor a sua biblioteca.

Tais preceitos serão aliados à concepção da dupla estrutura formal do conto, conforme dispõe Ricardo Piglia em Teses sobre o conto (2004). O escritor e ensaísta argentino defendeu a tese de que um conto sempre narra duas histórias: a primeira contém intrinsecamente uma segunda e esta é a chave formal do conto e das suas variantes, constituindo-se e percebendo-se pelo não dito, pelo que está subentendido. O texto recorre, ainda, à teoria do iceberg, de Hemingway (1988), ou seja, o conto possui uma narrativa que se mostra à superfície, uma ponta visível que se encontra sobre a água; porém, submersa e quase invisível, encontra-se a estrutura de base do iceberg arquitetado por um universo simbólico que, quando desvendado, faz aparecer artificialmente algo que está oculto. Esta revelação reproduz/renova uma experiência única de vida, uma verdade secreta que se deixa desvendar. No caso em questão, tal experiência refere-se a uma viagem pela vida de Machado de Assis e pela história da literatura, como é revelado no conto de João Padilha (1988), resultando em uma metaficção historiográfica que aparece "especificamente duplicada em sua inserção de intertextos históricos e literários", pois as

[...] recordações gerais e específicas das formas e dos conteúdos da redação da história atuam no sentido de familiarizar o que não é familiar por meio de estruturas narrativas [...] [e] sua auto-reflexividade metaficcional atua no sentido de tornar problemática qualquer dessas familiarizações (HUTCHEON, 1991, p. 168).

A narrativa em análise está circunscrita por três histórias: a primeira é contada por um narrador-conferencista e revela seu encontro com o professor Otacílio da Silveira; a segunda é narrada pelo professor Otacílio e apresenta detalhes sobre um encontro que teve com o mestre Machado de Assis; a terceira história é narrada "pela" voz de Machado de Assis, mas no corpo do professor Otacílio. Todas elas vinculam-se à memória do conferencista. 
Viagens e Viajantes na História da Literatura inscreve-se, também, no subgênero metaliterário de feição autobiográfico, característico da segunda metade do século 20 , em que os escritores pós-modernos,

Em busca de novos rumos, [...] olham, com uma nostalgia que não os paralisa, para seus antepassados, cujas vidas e obras eles revitalizam em obras que trazem a marca de nosso tempo. A escrita de cada um deles não é uma imitação anacrônica e estéril. Esses romances sobre escritores são, como dizia Carlyle há quase dois séculos e Mallarmé há pouco mais de um, belas tumbas (tombeaux): enterros e celebrações, ambos necessários para que a literatura, assumindo novas formas, prossiga (PERRONE-MOISÉS, 2016, p. 147-148, grifos da autora).

A partir dos preceitos arrolados, o presente trabalho investiga aspectos da estrutura submersa do conto Viagens e viajantes na História da Literatura, para perceber a sustentação deste iceberg e da presença de "formas de intertextualidade", como a referência, a alusão, o pastiche e a inclusão de fragmentos sem aspas, "cuja identificação é deixada a cargo dos iniciados" (PERRONE-MOISÉS, 2016, p. 146). Tal base reverbera as vozes da origem da forma do conto e a sua ressignificação.

\section{Viagens e Viajantes: a Conferência e os encontros textuais}

O conto objeto começa introduzido pela epígrafe: Eu creio que o mar batia na pedra como é seu costume desde Ulisses e antes, que remete ao capítulo "CXVII - Amigos próximos", do romance Dom Casmurro, de Machado de Assis (1961). Tal elemento paratextual endereça ao leitor a fala de Bento Santiago, o velho Dom Casmurro, que cita e questiona a veracidade do discurso de um historiador:

Um historiador da nossa língua, creio que João de Barros, põe na boca de um rei bárbaro algumas palavras mansas, quando os portugueses lhe propunham estabelecer ali ao pé uma fortaleza, dizia o rei que os bons amigos deviam ficar longe uns dos outros, não perto, para se não zangarem como as águas do mar que batiam furiosas no rochedo que eles viam dali. Que a sombra do escritor me perdoe, se eu duvido que o rei dissesse tal palavra nem que ela seja verdadeira. Provavelmente foi o mesmo escritor que a inventou para adornar o texto, e não fez mal, porque é bonita; realmente, é bonita. Eu creio que o mar então batia na pedra, como é seu costume, desde Ulisses e antes. Agora que a comparação seja verdadeira é que não (ASSIS, 1961, p. 367-368).

O trecho supracitado nos antecipa sobre a construção narrativa de Viagens e Viajantes na História da Literatura, uma vez que, enquanto toma para si a estilística metatextual machadiana, parodia o capítulo referido de Dom Casmurro, transformando a sua narrativa e reutilizando os cernes temáticos. Neste caso, a escrita funciona como a memória do autor, sua biblioteca, e, como nos é revelado, "toda biblioteca, como todo museu, escolhe, esquece, classifica, arquiva, celebra” (ACHUGAR, 1994, p. 14, tradução nossa).

Para Genette (2009), o paratexto de uma obra é 
aquilo por meio de que um texto se torna livro e se propõe como tal a seus leitores [...] um limiar, ou - expressão de Borges ao falar de um prefácio - de um "vestíbulo", que oferece a cada um a possibilidade de entrar ou de retroceder. "Zona indecisa" entre o dentro e o fora, sem limite rigoroso, nem para o interior do (o texto) nem para o exterior (o discurso do mundo sobre o texto), [...] constitui entre o texto e o extratexto uma zona não apenas de transição, mas também de transação: lugar privilegiado de uma pragmática e de uma estratégia, [...] uma melhor acolhida do texto e de uma leitura mais pertinente. (2009, p. 9 , grifos do autor).

A epígrafe em questão atua como uma porta de entrada para a obra analisada, estabelecendo uma ponte entre um dentro e um fora, mais precisamente instaurando os acessos ao seu interior, provocando, assim, estranhamentos e descobertas durante a leitura da narrativa, motivo pelo qual a recepção do paratexto resulta decisiva para a interação entre a estrutura da obra e seu receptor, convocado a ativar a memória da sua biblioteca para poder decifrar e ressignificar o texto. Desta maneira, o leitor é convidado a realizar uma leitura palimpséstica para revelar os signos crípticos de um passado que transforma o presente narrativo. Para Piglia (2004) a primeira síntese desse processo de transformação remete à teoria do Iceberg de Hemingway (1988), ou seja, a história secreta se constrói com o não dito, com o subtendido e a alusão; o mais importante nunca se conta.

A narrativa de Viagens e Viajantes na História da Literatura começa com o agradecimento do conferencista ao professor Otacílio da Silveira em virtude do auxílio prestado pelo segundo no aprimoramento de uma conferência proferida no ano de 1947, que versava sobre viagens e viajantes na história da literatura. $O$ texto integral da conferência perde-se após o conferencista emprestá-lo a uma das suas espectadoras. Embora tenha tentado reescrever o texto original, isso não foi possível, pois a sua memória já carregava uma nova narrativa que impedia a primeira de retornar à superfície, e assim começa o palimpsesto do conto em análise.

$\mathrm{Na}$ sua conferência, o também narrador do conto segue os passos das viagens das personagens dos grandes autores europeus que fazem parte do cânone universal da alta cultura hegemônica europeia. As "páginas dos célebres autores universais" (PADILHA, 1998, p. 64) que percorre são de Chrétien de Troyes, Dante, Camões, Cervantes, Defoe, Swift, Stevenson, Verne, Mann e outros que foi "encontrando pelo caminho" (PADILHA, 1998, p. 64). Esta viagem sumária por uma parcela dos países e autores europeus permite inferir sobre o particular (local) e o universal, partindo de um lugar que não está diretamente relacionado àquilo que se convencionou chamar de centro cultural.

O professor Otacílio retruca ao conferencista sobre a ausência de Machado de Assis entre os autores referidos na conferência. O conferencista responde-lhe que “[...] não havia remédio senão deixar de fora um autor que de viagens - ou descrição de viagens - não tivera experiência" (PADILHA, 1998, p. 65), ao que o professor objeta: "Toda essa gente viajou: Xavier de Maistre à roda do quarto, Garret na terra dele, Sterne na terra dos outros. De Brás Cubas se pode talvez dizer que viajou a roda da vida" (PADILHA, 1998, p. 66). Essa citação, que Otacílio conhecia de cor, pertence ao prólogo da quarta edição das Memórias póstumas de Brás Cubas. Embora Machado de Assis nunca tenha saído dos limites do Rio de Janeiro, 
construiu uma obra que, em muitas ocasiões, trata de paragens estrangeiras ou tem como tema a viagem. Se Brás Cubas é o defunto autor que viaja "à roda da vida”, Machado também viajou como leitor à roda de Maistre, Garret, Sterne e tantos outros.

O professor Otacílio demonstra grande interesse pela passagem da conferência que discorre sobre a "combinação binária de impressões visuais fugazes" (PADILHA, 1988, p. 70), que leva a personagem de Mann a introjetar na sua cabeça a ideia de viajar a Veneza, onde irá morrer. Segundo o professor, foi esta combinação binária de impressões visuais fugazes de um inglês e umas estampas do Lloyd representando barcos a vapor, que levaram Machado, estando num café diante de uma xícara de chá, a traçar grandes planos de viagem, nos idos anos de 1907, ano anterior ao seu falecimento.

O inglês e as estampas do Lloyd representando barcos a vapor, somados à imagem de Machado num café, levam ao leitor do conto objeto a possibilidade de transportar Machado diretamente à Europa ou, ainda, adivinhar o seu secreto anseio: tornar-se um escritor universal e, para isto, precisava ser traduzido. Desde 1888, o próprio Machado já tentava ver-se traduzido, mas a autorização necessária foi sistematicamente negada por seu editor, H. Garnier, como atesta a correspondência trocada entre eles (SOUZA, 1958). Tem início, a partir desta instância narrativa, uma combinação entre ficção e dados biográficos e entre história e ficção. Segundo Perrone-Moisés (2016, p. 131), esse tipo de narrativa, que tem como personagem um grande escritor, quer dizer, um grande herói da literatura na sua época áurea, é um fenômeno que cresceu sensivelmente desde os anos 80.A autora explica, ainda, que, segundo Dosse (apud PERRONE-MOISÉS, 2016), o crescimento do subgênero ocorre pela

humanização das ciências humanas, a era do testemunho, a busca de uma unidade entre o pensar e o existir, o questionamento dos sistemas holísticos, assim como a perda da capacidade estruturante dos grandes paradigmas, todos esses elementos contribuem para o entusiasmo atual pelo biográfico. (DOSSE, 2005, p. 13; 448 apud PERRONE-MOISÉS, 2016, p. 133).

A autora esclarece (2016) que o subgênero em questão não pretende ater-se à biografia conhecida de seus heróis; pode-se inventar outros episódios ou tratar livremente episódios conhecidos. Muitos escritores relatam os últimos dias e a morte do escritor em pauta, como é o caso do conto de José Padilha, "provavelmente porque esses últimos momentos permitem um balanço de sua existência e de suas obras" (PERRONE-MOISÉS, 2016, p. 133). Assim, enquanto o leitor lê Viagens e Viajantes na História da Literatura, vai conhecendo os interstícios da escrita machadiana, a relação entre o pensar e o existir do mestre e, ainda, enquanto o leitor vai constatando fatos biográficos verídicos do escritor personagem passa também a ser um viajante na história da literatura; neste caso, viaja à roda da vida de Machado de Assis.

Voltando ao conto em análise, com Machado transportado pela combinação binária de imagens para a Europa, “o castelo no ar do velho mestre" (PADILHA, 1988, p. 70), como salienta Otacílio, o texto aponta, imediatamente, para a representação da Europa na obra machadiana. Tal aspecto, que não escapa ao atento ouvinte, serve também para mostrar que 
Machado, ao enviar seus personagens à Europa, imprime a eles um castigo. Não seria esse o estilo machadiano? Enquanto alude à literatura francesa, tão universal na sua época, também castiga suas personagens que adquirem o ar de grandeza napoleônico, tão típico da sociedade brasileira do final do século 19, que travava uma luta pela identidade nacional atrelada às ideologias europeias, em que a elite escravocrata, ilusoriamente liberal, permanece indecisa entre optar por conservar seus privilégios ou apropriar-se do discurso democrata liberal europeu.

- Ali! - insistiu o professor - ali, à mesa de um café que não existe mais, e cuidando para não ser notado, Machado curtia a tensão entre fazer a Europa e o medo de, uma vez lá, ser tido como uma espécie de José Dias, cuja vista se turvava pela fascinação superlativa do Velho Mundo (PADILHA, 1998, p. 72).

O superlativo machadiano está no fazer a Europa ao estilo brasileiro. Ele parodia as grandes narrativas francesas universais, como é possível ver em muitas das suas narrativas. A título de exemplo, podemos tomar o capítulo L, de Memórias póstumas de Brás Cubas, que parodia o Canto $V$, de $A$ Divina Comédia, e que trata do reencontro entre Brás e Virgília, quando Brás Cubas fala: "Um livro perdeu Francesca; cá foi a valsa que nos perdeu” (ASSIS, 1994b, p. 58). Esse trecho remete à cena em que Virgília, já casada com Lobo Neves, dança com Brás num baile, e os dois são incendiados pela sensualidade da valsa. Esta situação é diferente da cena que acontece na obra de Dante (2009), em que os cunhados Paolo e Francesca se deixam empolgar pelo trecho de um livro que resulta em um beijo trêmulo, quase casto, mas são surpreendidos e mortos pelo marido traído. Já em Memórias póstumas de Brás Cubas, há a transgressividade da cena: Virgília e Brás Cubas começam a sua aventura adúltera, que será vivida impunemente, embora sem "carnes febris" e tudo atenuado pela "surdina do estilo". Outro elemento transgressor em Memórias póstumas é o fato de Brás Cubas desfilar alegoricamente morto entre os vivos, enquanto Dante é um homem vivo que circula entre os mortos.

Retoma-se, agora, novamente, a citação sobre José Dias, "cuja vista se turvava pela fascinação superlativa do Velho Mundo" (PADILHA, 1998, p. 72) e por quem Machado não queria ser comparado uma vez na Europa, ciente de que, para os olhos europeus, ser um escritor "brasileiramente" original significava ser exótico e indianista. Machado, porém, como é sabido, não se enxergava por esse espelho, pois expressa no seu ensaio Instinto de Nacionalidade (1873) o seguinte:

Não há dúvida que uma literatura, sobretudo uma literatura nascente, deve principalmente alimentar-se dos assuntos que lhe oferece a sua região; mas não estabeleçamos doutrinas tão absolutas que a empobreçam. O que se deve exigir do escritor, antes de tudo, é certo sentimento íntimo, que o torne homem do seu tempo e do seu país, ainda quando trate de assuntos remotos no tempo e no espaço (ASSIS, 1994a, não paginado).

Diga-se agora que quem sabia, também, de assuntos remotos no tempo e espaço, era o 
professor Otacílio, "que tudo observava da rua pela vidraça do café" (PADILHA, 1998, p. 73) em que Machado se encontrava no ano de 1907e, assim, o traz à vida em 1947. Naquele café, em que o mestre mapeava seu destino, Otacílio adivinhava-lhe, ou melhor, traduzia-lhe os pensamentos. Dizia o professor que Machado, "na convicção de ver encerrada sua carreira literária [...] não conseguia fazer outra coisa [...] senão embarcar mentalmente rumo a Europa" (PADILHA, 1998, p. 73). Estava o escritor fluminense

[...] se imaginado em plena viagem, morrendo, e uma vez morto, servindo seu cadáver a uma cerimônia rápida presidida pelo capitão do navio, ao cabo do qual seu esquife simples era lançado aos peixes num dia nublado, ao sabor da observância de algum moço, que como Brás Cubas, anotaria (com voz grave, o professor Otacílio inicia uma citação): "A vaga abriu o ventre, acolheu o despojo, fechou-se. - uma leve ruga - e a galera foi andando. Eu deixei-me estar alguns minutos, à popa, com os olhos naquele ponto incerto no mar em que ficou um de nós (PADILHA, 1998, p. 73, grifos do autor).

O trecho supracitado é paródia e pastiche pelo seguinte motivo: a situação imagética em que se encontra Machado alude à cena em que Brás Cubas volta-se para Pandora e pede a ela que o devore: "Vamos lá, Pandora, abre o ventre, e digere-me; a coisa é divertida, mas digereme" (ASSIS, 1994b, p. 12). Pandora é representada aqui pela morte, quando Machado se imagina sendo devorado; a outra instância narrativa à qual se alude trata do episódio em que Brás Cubas fala sobre a morte e o sepultamento da mulher do capitão na viagem que o levaria a Portugal. O corpo da mulher é lançado ao mar, "à cova que nunca mais se abre": "A vaga abriu o ventre, acolheu o despojo, fechou-se" (ASSIS, 1994b, p. 30). O que temos aqui é uma paródia por transformação semântica, ou seja, o trecho transpõe a ação de Brás Cubas para a ação de Machado. E essa paródia não é, ao mesmo tempo, também paródia sobre a "combinação binária de impressões visuais fugazes" (PADILHA, 1998, p. 65) que leva o personagem de Mann a introjetar em sua cabeça a ideia de viajar a Veneza onde irá morrer? Então, o que se nos apresenta aqui em Viagens e Viajantes na História da Literatura é uma narrativa que se vai construindo por meio da paródia, como uma matrioska russa, que o leitor tem de ir desmontando e montando. E não é este o estilo de Machado? Entrelaçando sempre várias narrativas, dizendo algo que está oculto e que o leitor deve desbravar? "Residirá a paródia no olhar do observador? A acentuação dada à pragmática da paródia, bem como às suas propriedades formais, terá talvez sugerido que assim o é" (HUTCHEON, 1989, p. 107). Seguindo o caminho pragmático da paródia, Hutcheon (1989) destaca que

quando chamamos a alguma coisa paródia, postulamos alguma intenção codificadora que lance um olhar crítico e diferenciador ao passado artístico, uma intenção que nós, como leitores, inferimos então, a partir da sua inscrição (disfarçada ou aberta) no texto (1989, p. 108, grifo da autora).

Infere-se em Viagens e Viajantes na História da Literatura um olhar crítico sobre a obra machadiana, como destaca, metaforicamente, o professor Otacílio: "não é curioso esse mar coveiro de Machado que abre uma 'leve ruga' para admitir cadáveres"; ao que o conferencista 
lhe responde: "O mar não abre uma leve ruga quando recebe um volume pesado; espirra água para todos os lados, como estrondo...". "Precisamente”, aponta Otacílio, "o mar de Machado tem uma água alegoricamente densa, inatural" (PADILHA, 1998, p. 74, 75). Eis que o mar de Machado, e por mar entenda-se narrativa, é alegórico, um mar densamente construído por metáforas que funcionam como "[...] um poderoso instrumento para a construção analógica de pontes entre os temas considerados" (MACHADO, 2002, p. 13); e, ainda, para J.L. Borges, funcionam como "uma simpatia secreta entre conceitos" (BORGES apud MACHADO, 2002, p. 13). Esse denso mar alegórico que se apodera do cânone literário para construir, a partir disso, uma obra nova ao estilo brasileiro, era a maneira de o mestre assegurar o direito à universalização da literatura por oposição ao ponto de vista que somente reconhece espírito nacional nas obras que tratam do assunto local (SCHWARZ, 1990). É como explica o "Bruxo do Cosme Velho" em Instinto de Nacionalidade (1873)

que neste ponto manifesta-se às vezes uma opinião, que tenho por errônea: é
a que só reconhece espírito nacional nas obras que tratam de assunto local,
doutrina que, a ser exata, limitaria muito os cabedais da nossa literatura [...]
Mas, pois que isto vai ser impresso em terra americana e inglesa, perguntarei
simplesmente se o autor do Song of Hiawatha não é o mesmo autor da Golden
Legend, que nada tem com a terra que o viu nascer, e cujo cantor admirável é;
e perguntarei mais se o Hamlet, o Otelo, o Júlio César, e Julieta e Romeu [sic]
têm alguma coisa com a história inglesa nem com o território britânico, e se,
entretanto, Shakespeare não é, além de um gênio universal, um poeta
essencialmente inglês [...] (ASSIS, 1994a, não paginado).

Falando-se em bruxos, volte-se a um que acredita "ter chegado à adivinhação completa do pensamento que ele [Machado] ruminava naqueles momentos" (PADILHA, 1998, p. 74) e perguntemos: será que o professor Otacílio “tem quatro estômagos no cérebro, e por eles faz passar e repassar os atos e os fatos, até que deduz a verdade, que estava, ou parecia estar escondida"? (ASSIS, 2003, p. 79); digamos que sim, pois o Bruxo do Cosme Velho já disse, em Esaú e Jacó, que "O leitor atento, verdadeiramente ruminante" (ASSIS, 2003, p. 79), é possuidor de tais estapafúrdias características.

Otacílio, que tudo vê pela vidraça do café, no ano de 1907, com a cabeça colada à vidraça, chegando a embaçá-la com a sua respiração, "para não deixar escapar nenhum movimento, nenhuma expressão do mestre" (PADILHA, 1998, p. 74), conta ao conferencista que Machado já deixara os lúgubres pensamentos, pois “já se via em Paris, são e salvo, bem de saúde e de espírito" e parte para "viver o momento culminante da viagem, e provavelmente da sua carreira literária: a sessão solene em sua homenagem [...] presidida por Anatole France" (PADILHA, 1998, p. 76, 75). Temos aqui outra constatação, mas esta se refere a uma homenagem póstuma que recebeu o mestre. A homenagem aconteceu no dia 3 de abril de 1909 , em Paris, na "Fête de l'intellectualité brésilienne" (STAUT, 1989, p. 280) cuja finalidade era 
homenagear Machado de Assis, falecido no ano anterior, e difundir sua obra na França. Organizada pela Société des Etudes Portugaises de Paris, a festa realizou-se no Amphithéâtre Richelieu da Sorbonne, com a participação de Anatole France. Na sessão solene em sua homenagem, Machado diria:

- Je tiens à vous remercier de votre accueil dan ce temple majeur de la culture française, qui atteint, lorsque vous recevez ce représentant de la littérature de l'Amérique, une dimension vraiment universelle. Encore une fois, l'esprit français rend honneur à la voix du Noveau Monde... l'esprit français... Como se dizia no antigo Alcazar: vous avez d'esprit? Nous aussi ${ }^{1}$. (PADILHA, 1998, p. 76).

$\mathrm{O}$ que Machado poderia ter dito com outras palavras, se não fosse dissimulado e perspicaz, seria: - Quero agradecer-lhe por suas boas-vindas neste importante e hegemônico templo da cultura francesa, que atinge pela primeira vez, recebendo este representante da literatura americana que não escreve sobre o índio e a natureza exótica, uma dimensão verdadeiramente universal. E ainda poderia acrescentar: - quero agradecer pelo memorável espaço que representa a cultura francesa na cidade fluminense, aquele espaço que um tal Doutor Semana descrevera muito bem como (fazendo uma citação que sabia de cor):

um estabelecimento, onde, todas as noites, por entre baforadas de fumo e de álcool, se vê e se ouve aquilo que nossos pais nunca viram nem ouviram, embora se diga que é um sinal de progresso e de civilização. Chama-se esse estabelecimento - Alcazar Lírico (ASSIS, 1864, p. 29 apud NASCIMENTO, 2017, p. 203).

E para não ficar mal-entendido, pediria licença para ler um trecho de seu prólogo de Memórias póstumas de Brás Cubas, que diz o seguinte:

O que faz do meu Brás Cubas um autor particular é o que ele chama de "rabugens de pessimismo". Há na alma deste livro, por mais risonho que pareça, um sentimento amargo e áspero, que está longe de vir dos seus modelos. É taça que pode ter lavores de igual escola, mas leva outro vinho. Não digo mais para não entrar na crítica de um defunto autor, que se pintou a si e a outros, conforme the pareceu melhor e mais certo (ASSIS, 1997, p. 512).

Embora direto, objetivo e reto, o suposto Machado perceberia um olhar de interrogação na sua plateia. Já cansado, diria: - Oras! Se eu me pintasse de índio e exótico, ainda estariam me enxergado pelo olhar do colonizador.

Deixando as suposições de lado, que, mais que suposições, são uma análise do conto objeto, assinale-se que o Bruxo do Cosme Velho nada tem de direto e reto e sim tudo de "[...] enigmático e bifronte, olhando para o passado e para o futuro, escondendo um mundo estranho

\footnotetext{
1 "Gostaria de agradecer-lhe pelas suas boas-vindas neste importante templo da cultura francesa, que atinge, quando você recebe este representante da literatura americana, uma dimensão verdadeiramente universal. Mais uma vez, o espírito francês presta homenagem à voz do Novo Mundo ... o espírito francês ... Como no antigo Alcazar: você tem inteligência? Nós também". (PADILHA, 1998, p. 76, tradução nossa).
} 
e original sob a neutralidade aparente das suas histórias 'que todos podiam ler"' (CANDIDO, 2004, p. 17). Acontece, como já assinalado, que o mar machadiano não espirra água para todos os lados, mas abre uma leve ruga.

Voltando às leituras das ruminações machadianas, muito bem feitas pelo professor Otacílio e relembradas pelo conferencista, Machado continua, na voz de Otacílio, dizendo naquela sessão solene: - "Mis l'sprit français n'ouvrira ni ses yeux ni ses oreilles... et Anatole France, ce vieux sourd, dira des tas de choses à mom égard qui n'auront rien à voir avec moi..."2 (PADILHA, 1998, p. 76). De fato, como relata Staut em Machado na França:

Com efeito, a latinidade marca o tom geral dos discursos proferidos na Sorbonne; o gênio latino de Machado de Assis é saudado e, até certo ponto, encampado pela ideologia francesada época. Os traços de sua obra, ironia, equilíbrio, harmonia, são apontados pelos conferencistas como decorrência de sua natureza latina, que o aproxima de Mérimée, Renan e do próprio Anatole France, apesar de seu humor mais próximo dos ingleses. Muito francês e pouco exótico, o autor brasileiro projetou, na França, uma imagem que seria também a do Brasil: para uma parte da intelectualidade francesa da época, nosso país se reduziria a um espelho da latinidade e, seu escritor maior, a uma espécie de escriba francês à brasileira (STAUT, 1989, p. 281).

Assim ficava o mestre condenado por um erro de estratégia: o da latinidade. Segundo Pierre, "que interesse poderia ter para o público francês uma espécie de discípulo distante de Renan ou Anatole France, que nem sequer teve o privilégio de escrever uma obra exótica?" (PIERRE, 1976, p. 245 apud STAUT, 1989, p. 281, tradução nossa).

Machado continua na voz de Otacílio:

Eu direi: J'ai traversé l'océan Atlantique comme si je me promenais par la rue do Ouvidor... e a sessão se encerrará por falta do que dizer, et lês deux esprits, le brésilien et le français, seront em face l'um de l'autre, muets épuisés et vaincus, à la fin d'une bataille qui n'aura jamais commecé. Hélas! ${ }^{3}$ (PADILHA, 1988, p. 76).

Partindo desse discurso, pode-se inferir que a Rua do Ouvidor não representava uma ponte entre o Brasil e a França e sim o oceano que separava ambos os países, disfarçado numa aparente convivialidade da diferença marcada por um gesto transculturador recebido do grande centro hegemônico francês, que, para o mundo literário, era simbolizado pela Editora Garnier, em que os escritores brasileiros começaram a alimentar o sonho de ali fazerem presentes os seus textos um dia e, melhor ainda, serem traduzidos para o francês. Assim, a França transforma-se no referente cultural definidor por excelência das hierarquias que fazem ao escritor brasileiro olhar para seu país em busca do aspecto pitoresco e exótico que tanto agrada

\footnotetext{
2 "Mas o espírito francês não abrirá os olhos nem os ouvidos ... e Anatole France, este velho surdo, dirá muitas coisas para mim que nada terão a ver comigo". (PADILHA, 1998, p. 76, tradução nossa).

3 "Diremos todos em coro, como se brindássemos funebremente à nossa derrota... Hélas! Atravessei o Oceano Atlântico como se estivesse andando pela Rua do Ouvidor...e a sessão se encerrará por falta do que dizer, e os dois espíritos, o brasileiro e o francês, se enfrentarão mutuamente, exaustos e vencidos, no final de uma batalha que nunca terá começado. Hélas!” (PADILHA, 1988, p. 76, tradução nossa).
} 
aos olhos estrangeiros. Deste modo, tal apelo institucionaliza-se como elemento definidor da originalidade e identidade nacional com o Romantismo, e é desta maneira que se trava uma batalha para a construção da nação brasileira mediante a imagem fornecida pelo espelho europeu... Hélas!

\section{O fim da viagem e o início da vida-texto}

Voltando às personagens desta viagem pela história da literatura, estava o conferencista junto ao professor Otacílio ao lado da chapelaria, antiga cafeteria da Rua do Ouvidor. Otacílio olhava pela vitrina, "sua respiração embaçava o vidro"; olhava como quem quer cavar uma história. O conferencista, contudo, "tinha os olhos no mesmo ponto, mas só via chapéus sem cabeça", e Otacílio continuava, com "aquele nariz encostado na vidraça de uma chapelaria, a tentativa de ver alguma coisa que não fossem apenas chapéus". Isto pareceu "insuportável” ao conferencista, motivo pelo qual resolveu "ficar de costas para aquela vidraça, olhando para as poças d'água da Rua do Ouvidor [...]" (PADILHA, 1988, p. 77, 78). O que é apresentado nestas cenas da narrativa é o posicionamento do leitor: por um lado, temos o leitor ruminante, já referido anteriormente, e, por outro, aquele mencionado por Brás Cubas, quando descreve:

Mas o livro é enfadonho, cheira a sepulcro, traz certa contração cadavérica; vício grave, e aliás, ínfimo, porque o maior defeito deste livro és tu, leitor. Tu tens pressa de envelhecer, e o livro anda devagar; tu amas a narração direta e nutrida, o estilo regular e fluente, e este livro e o meu estilo são como os ébrios, guinam à direita e à esquerda, andam e param, resmungam, urram, gargalham, ameaçam o céu, escorregam e caem (ASSIS, 1994b, p. 78).

Enquanto uns são olhadores de poças, pelo que fica descrito, outros são

caçadores de poços e construtores de casas, os leitores são viajantes; circulam nas terras alheias nômades caçando por conta própria através dos campos que não escreveram, arrebatando os bens o Egito para usufruí-los [...] (CERTEAU, 1994, p. 269-270 apud SOUZA, 2010, p. 178).

Assim como Machado aponta o caminho de leitura para seus leitores, Padilha também indica o caminho de leitura de maneira menos direta, por meio de muitos referentes que surgem como uma metáfora de leitura. Ela representa uma forma de se percorrer o corpo machadiano, identificado pela leitura palimpséstica. Embora esses autores indiquem o caminho, quem o percorre é o leitor que, solitário, escolhe como empreender a viagem, podendo perder-se olhando poças ou ser um caçador de poços. Para muitos criadores, essa é uma estratégia narrativa que sinaliza um modo de operar, relacionando as práticas de leitura e releitura. Dessa forma, em Viagens e Viajantes na História da Literatura, o leitor é convidado a ser mais um viajante, e, para esse empreendimento, deve ativar um determinado repertório que equivale a mover-se entre uma vasta série de tradições literárias. No conto em questão, o percurso produz vínculos com as impressões deixadas pelo professor Otacílio, com e pelo entrecruzamento do ficcional e do biográfico e entre a estória e a história.

A respeito desta viagem tenha-se presente o que já advertiu Ricardo Piglia (2004, p. 89), 
quando afirmou que "um conto sempre conta duas histórias": uma história visível e outra secreta. $\mathrm{O}$ autor precisa ter em mente a segunda história a fim de que a primeira apresente os elementos da história secreta que está sendo narrada de modo elíptico. Assim, a tensão que se cria a partir dos elementos que constituem as duas histórias deve ser mantida até que a história secreta desponte. $\mathrm{O}$ que era acessório na história visível se mostra essencial à história secreta. Essa ideia aparece sintetizada no "princípio do iceberg", de que fala Ernest Hemingway (1988, p. 67): “[...] só se vê um oitavo, os outros sete estão debaixo d'água. Tudo o que você sabe e pode eliminar só fortalece o iceberg". A ponta do iceberg do conto objeto relata o encontro do professor Otacílio que, quando jovem, conheceu Machado de Assis quando este estava encerrando sua carreira. Por meio de uma série de ruminações, no entender de Otacílio, o autor de Dom Casmurro traça planos de viagem. O que subjaz à história dois, de João Padilha (1998), é a matéria de criação literária que resulta em uma poética da escrita machadiana.

Retornando novamente ao enredo do conto, temos as duas personagens, Otacílio e o narrador-conferencista, caminhando "de braços dados, em silêncio, seguindo pedra por pedra o trajeto cumprido naquela tarde de 1907" (PADILHA, 1998, p. 83) pelo professor e por Machado, enquanto dirigiam-se ao prédio onde, naqueles tempos, funcionara a Livraria Garnier, e que, no atual ano narrativo de 1947, era um depósito de bebidas (PADILHA, 1988, p. 83). Uma vez à frente de onde fora a Editora, Otacílio relembra o momento em que acompanhou o mestre no ato de entrega de seu último livro, o Memorial de Aires. Otacílio conta que naquele lugar, enquanto Machado dormitava, ele lia o Memorial, até que chega a leitura do dia 5 de fevereiro do diário, e que, a partir daí, passou a folhar "abrangentemente os originais". Eis que nesse dia o conselheiro Aires escreve: "Relendo o que escrevi ontem, descubro que poderia ainda ser mais resumido, e não disse tudo" (ASSIS, 1976, p. 28) Então, enquanto Otacílio lê o original aproveita o processo criativo de um modo que o material editado já não mostraria motivo pelo qual afirma a Machado:

"É o seu livro mais bonito" [...]. "Mas deveria ser publicado assim, em forma manuscrita. A letra da imprensa vai descuidar um pouco a sua beleza." [...] o leitor precisa gozar, neste livro, não só a literatura mas também a intimidade do gesto que a livrou" (PADILHA, 1988, p. 85).

E não é sobre intimidade criadora que fala a narrativa? O que se depreende do Memorial de Aires é um fazer literário subversivo, típico do estilo machadiano, que não gostava de seguir os ditames das escolas europeias, que o limitavam a um escritor periférico. O Memorial de Aires

[...] está no núcleo da articulação entre o registro de diário íntimo e o de romance operada pelo narrador do Memorial. [...] ao passar de um gênero para o outro, o conselheiro Aires frustra as expectativas legítimas do leitor em relação a cada um deles, de modo que, à primeira vista, nem o romance nem o diário íntimo cumprem o que, até os inícios do século XX, de hábito prometiam. Aires oferece ao leitor, por um lado, uma história narrada sem objetividade e turvada de obscuridades, ao contrário do romance realista tradicional; por outro, um diário íntimo no qual o diarista, esquivo, não se dá 
por achado em sentido oposto ao de costume (FRAGELLI, 2010, p. 48, 51).

Agora quem compulsava o manuscrito era Machado de Assis, "na forma do professor Otacílio"; o conferencista conta que Machado, no corpo do amigo

Deparou-se, casualmente, com um trecho que o interessou. Era o último parágrafo do diário de Aires correspondente à data de 10 de abril de 1988 que descreve o momento em que o tio e o pai de Fidélia decidem redigir uma carta de alforria em que se concedia liberdade coletiva aos escravos da fazenda da família. Machado de Assis [...] lê em voz alta: "Retendo o papel, Santa-Pia disse: - Estou certo que poucos deles deixaram a fazenda; a maior parte ficará comigo, ganhando o salário que lhes vou marcar, e alguns até sem nada" (PADILHA, 1998, p. 87).

Logo, Machado "molha a pena no tinteiro que lhe tinha sido arrastada pela mão do jovem Otacílio, e inscreve alguma coisa no papel” (PADILHA, 1998, p. 87); coisa que depois o conferencista vai verificar no seu exemplar do Memorial de Aires e, assim, constata que "Machado tinha feito um acréscimo naquela frase: transformou o ponto em vírgula, abriu um travessão e escreveu: "pelo gosto de morrer onde nasceram" (PADILHA, 1998, p. 87).

A certeza de Santa-Pia demonstra que, mesmo alforriados, os escravos não abandonariam as terras em que viviam, aceitando trabalhar por qualquer salário ou mesmo de graça, por amor à terra, por serem nacionalistas, "pelo gosto de morrer onde nasceram" (PADILHA, 1998, p. 87). Tal fato não somente acarreta uma crítica à abolição, em que há pouca mudança da estrutura social, em que os ex-escravos, mesmo livres, continuarão presos à condição de trabalhadores rurais e à falta de oportunidades, ostentando, agora, uma liberdade que é muito mais ilusória do que real, como também permite fazer uma analogia com relação aos escritores do século 19 e 20, sejam estes românticos, naturalistas, realistas ou modernistas. Os escritores, já na condição de produzir numa ex-colônia, não deixam de acatar as normas das escolas europeias e, no caso de subversivos, não alcançariam a consagração como universais na época, uma vez que não agradariam aos centros literários hegemônicos. Assim, na posse de um discurso nacionalista, camuflavam-se ou enganavam-se enquanto ainda seguiam sendo uma espécie de literatos colonizados. Batista (2010, p. 7) destaca, parafraseando Pratt, que

[...] a visão ideológica da América como natureza foi incorporada pelos intelectuais americanos das ex-colônias por meio de um processo de transculturação, i.e., processo em que as elites das ex-colônias selecionam e adaptam as imagens criadas sobre eles pelos europeus com a intenção de seu próprio discurso de uma identidade cultural (PRATT, 1992, p. 112 apud BATISTA, 2010, p. 7).

A uma visão ideológica desta ordem, Lunardi (2007 apud CHIARELLI, 2016) responde:

na Europa, especialmente, espera-se da literatura brasileira um folclore de mulatas e palmeiras ou a cantilena de mazelas sociais e políticas. Sempre que posso denuncio essa expectativa, questionando por que razão a grande arte, os livros que mudam o mundo, seriam prerrogativa dos países desenvolvidos, enquanto a nós, os periféricos, restaria o relato antropológico de nossa miséria. 
(LUNARDI, 2007 apud CHIARELLI, 2016, p. 89).

Sobre o assunto, Machado de Assis (1873) já tinha se manifestado no seu Instinto de Nacionalidade:

[...] a civilização brasileira não está ligada ao elemento indiano, nem dele recebeu influxo algum; e isto basta para não ir buscar entre as tribos vencidas os títulos da nossa personalidade literária. Mas se isto é verdade, não é menos certo que tudo é matéria de poesia, uma vez que traga as condições do belo ou os elementos de que ele se compõe (ASSIS, 1994a, não paginado).

E era sobre isso que Machado de Assis pretendia que seus leitores inferissem, e talvez fosse esse o legado a ser deixado com o Memorial de Aires, principalmente quanto ao tópico da subversão dos gêneros. Se o corpo machadiano era alegoricamente constituído, por outro lado, jamais serviu aos ditames de uma escola hegemônica.

No final da narrativa de Viagens e Viajantes na História da Literatura, chegando-se ao ponto de táxi em que o professor Otacílio e o conferencista se separariam e onde foi o mesmo lugar em que o mestre Machado e o jovem Otacílio se despediram no ano de 1907, relata o narrador-conferencista: "Fomos caminhando novamente, os dois - eu e o professor Otacílio; eu e Machado de Assis; o jovem Otacílio e Machado de Assis - na direção do largo do Machado" (PADILHA, 1988, p. 88).

Quase no encerramento desta viagem à roda da vida de Machado, tem-se esse trecho que representa uma transfiguração de personagens e narrativas. Tal construção metafórica e metatextual alude à própria arquitetura da narrativa em análise, que relembra as matrioskas russas, uma história dentro de outra, de outra, de outra... Elas constituem uma história maior, mas, para saber o que constitui esta grande história, é necessário desmontá-la, é preciso submergir-se nas águas profundas do conto para descobrir o que há debaixo da ponta do iceberg narrativo e, assim, chegar à história dois, que é a chave da forma do conto e de suas variantes. O processo é também um método de leitura que serve para a narrativa machadiana, pois, enquanto o trecho citado fala da sua própria construção narrativa, também fala do fazer narrativo do Bruxo do Cosme Velho.

Já estavam, agora, no ponto de táxi, o conferencista e Otacílio, e este último prossegue seu relato:

- O bonde que levaria Machado de Assis vinha chegando. Beijei-lhe a mão e subi no tilbury. Parti. Já estava dobrando o largo quando, olhando para trás, vi o mestre sem olhos, porque eles haviam embarcado no meu carro; é o que concluo da cegueira com que ele não viu passar o seu bonde. - o professor deu uma risadinha autocondescendente: - Ai, requinte de estilo! (PADILHA, 1988, p. 89).

Em seguida se despedem o conferencista e o professor Otacílio, na seguinte cena descrita pelo primeiro:

O professor Otacílio [...] entrou no carro, deu um adeusinho pela janela 
fechada e seus lábios se moveram numa fala inaudível - cujo teor, não obstante, adivinhei facilmente. Ele sem dúvidas, dizia:

- À beira da calçada estava o conferencista sem olhos, porque eles haviam embarcado no meu carro; é o que concluo da cegueira com que ele não viu passar o seu bonde... Ai, que requinte de estilo! (PADILHA, 1988, p. 89).

Essas duas cenas fecham o processo elíptico da construção do conto objeto, pois a segunda é paródia da primeira, ou seja: citação recontextualizada. Para Piglia (2004), esse é o esquema/processo do conto, quer dizer, "um relato visível esconde um relato secreto, narrado de um modo elíptico e fragmentário.” (2004, p. 89). E esta paródia não poderia ter acontecido sem a outra paródia anterior: a da "combinação binária de impressões visuais fugazes" (PADILHA, 1998, p. 65), que faz parte de uma maior, a do capítulo "CXVII - Amigos próximos", de Dom Casmurro, e todas elas compõem a alegórica narrativa metatextual de "Viagens e Viajantes na História da Literatura", que se volta para o fazer narrativo machadiano e que, ao mesmo tempo, é uma metanarrativa historiográfica que exige do leitor não apenas o reconhecimento de vestígios textualizados do passado literário e histórico, mas também a percepção daquilo quem foi feito - por intermédio da ironia - a esses vestígios (HUTCHEON, 1991).

Ainda conforme a autora, a paródia está para a metanarrativa historiográfica como produção que tem o papel de

questionar a autoridade de qualquer ato de escrita por meio da localização dos discursos da história e da ficção dentro de uma rede intertextual em contínua expansão que ridiculariza qualquer noção de origem única ou de simples causalidade (HUTCHEON, 1991 p. 169).

É essa a mesma função que o mar, alegoricamente denso de Machado de Assis, pretende nas suas folhas que carregam a escrita do mundo, e que Umberto Eco (apud HUTCHEON, 1991) também percebeu ao escrever seu romance O Nome da Rosa: "Descobri o que os escritores sempre souberam (e nos disseram muitas e muitas vezes): os livros sempre falam sobre outros livros, e toda estória conta uma estória que já foi contada" (ECO, 1983, 1984, p. [20] apud HUTCHEON, 1991, p. 167) Diga-se de passagem, também, "que o mar" como se constata na epígrafe do conto de João Padilha, "então batia na pedra, como é seu costume, desde Ulisses e antes" (PADILHA, 1998, p. 62).

\section{Considerações finais}

Viagens e viajantes na História da Literatura resulta em uma poética da escrita machadiana que permite repensar a obra do autor de Dom Casmurro como uma narrativa de resistência aos grandes centros hegemônicos, como é o caso da França, para a época do escritor. Machado propunha um encontro dialético entre o que seria uma escrita nacional e universal, negando a obrigatoriedade de uma escrita exótica de cor local para anular a fronteira entre o local e o universal. Há um assunto que foi pouco abordado na análise do texto de João Padilha (1998), não por desinteresse ou omissão, mas é que os passos percorridos pelo professor 
Otacílio, e rememorados pelo conferencista, ocuparam a extensão desta análise: a memória como elemento narrativo, característico do subgênero autobiográfico e de tendência no cenário pós-moderno. O modo como a memória foi trabalhada por Padilha (1998), nesse jogo de narrativas que se interpõem, de corpos que se misturam compondo um só corpo narrativo, desconstrói também o esperado de um gênero autobiográfico, pois se a autobiografia é a de Machado de Assis, tem-se que ela é incorporada por um outro, que se confunde com o ser apropriado (Machado de Assis). Pode-se afirmar, portanto, que Viagens e viajantes na História da Literatura se constrói também como um ato contra os imperativos categóricos. A partir da reformulação no modo de organizar um corpus que abrange a metaliteratura, a metaficção autobiográfica, a metaficção historiográfica, e que ainda é construído pela dupla estrutura formal do conto, João Inácio Padilha (1998) demonstra com maestria um claro sintoma do sujeito pós-moderno, fragmentado, que já não se pode conter em apenas um eu categórico; pelo contrário, pode articular-se em várias formas narrativas num mesmo corpus, assim como Machado já o fazia no século 19.

\section{Referências}

ALIGHIERI, Dante. A divina comédia. São Paulo: Ed. 34, 2009.

ACHUGAR, Hugo. La biblioteca en ruinas: reflexiones culturales desde la periferia. Montevideo: Trilce, 1994.

ASSIS, Machado. Instinto de Nacionalidade. In: ASSIS, Machado. Obra Completa de Machado de Assis. v. III. Rio de Janeiro: Nova Aguilar, 1994a. Disponível em: http://www.letras.ufmg.br/padrao_cms/documentos/profs/sergioalcides/machadinstinto.pdf. Acesso em: 100-1/2019.

ASSIS, Machado de. Dom Casmurro. São Paulo: Mérito, 1961.

ASSIS, Machado de. Memorial de Aires. São Paulo: Ática, 1976.

ASSIS, Machado de. Memórias póstumas de Brás Cubas. In: ASSIS, Machado de. Obra completa. Rio de Janeiro: Nova Aguilar, 1997, p. 511-639. 1 v.

ASSIS, Machado de. Memórias póstumas de Brás Cubas. Rio de Janeiro: Editora Nova Aguilar, 1994b.

ASSIS, Machado de. Esaú e Jacó. São Paulo: Nova Cultural, 2003.

BATISTA, Eduardo L. A. O. Poética da representação cultural: relações entre literatura de viagem e tradução na literatura brasileira. 2010. 355 f.. Tese (Doutorado em Teoria e História Literária) - Instituto de Estudo da Linguagem, Universidade Estadual de Campinas, Campinas, 2010. Disponível em: http://www3.eca.usp.br/sites/default/files/webform/projetos/posdoc/Projeto\%20EB.pdf. Acesso em: 12/01/2019.

CANDIDO, Antônio. Esquema de Machado de Assis. In: CANDIDO, Antônio. Vários Escritos. São Paulo: Duas Cidades, 2004, p. 15-32. 
CHIARELLI, Stefania. De labirintos, corações e bibliotecas: encenações da leitura na ficção de Adriana Lunardi. Estudos de Literatura Brasileira Contemporânea, n. 48, p. 87-100, mai./ago. 2016.

FRAGELLI, Pedro. As formas e os dias. Revista USP Literatura e Sociedade, São Paulo, v. 15, n. 13, p. 46-65, nov. 2010. Disponível em: http://www.revistas.usp.br/ls/issue/view/5252. Acesso em 12/01/2019.

GENETTE, Gerárd. Palimpsestos: a literatura de segunda mão. Trad. de Luciene Guimarães e Maria Antonia Ramos Coutinho. Belo Horizonte: Faculdade das Letras, 2006.

GENETTE, Gerárd. Paratextos editoriais. São Paulo: Ateliê Editorial, 2009.

HEMINGWAY, Ernest. Os escritores: as históricas entrevistas da Paris Review. São Paulo: Companhia das Letras, 1988, p. 51-70.

HUTCHEON, Linda. Uma teoria da paródia. Lisboa: Edições 70, 1989.

HUTCHEON, Linda. Poética do pós-modernismo: história, teoria, ficção. Trad. de Ricardo Cruz. Rio de Janeiro: Imago Ed., 1991.

MACHADO, Nilson José. Matemática e educação - alegorias, tecnologias e temas afins. São Paulo: Cortez, 2002.

NASCIMENTO, Luciana. No ranger das rendas: o alcazar lírico na crônica cotidiana e na vida da cidade. Revista Anthesis. v. 5, n. 9, jan./jun., 2017.

PADILHA, João Inácio. Viagens e viajantes na história da literatura. In: PADILHA, João Inácio. Bolha de luzes. São Paulo: Companhia das Letras, 1998, p. 62-89.

PERRONE-MOISÉS, Leyla. Mutações da literatura no século XXI. São Paulo: Companhia das Letras, 2016.

PIGLIA, Ricardo. Teses sobre o conto. In: PIGLIA, Ricardo. Formas breves. São Paulo: Companhia das Letras, 2004, p. 87-94.

SAMOYAULT, Tiphaine. Intertextualidade. São Paulo: Hucitec, 2008.

SCHWARZ, Roberto. Um mestre na periferia do capitalismo: Machado de Assis. São Paulo: Duas cidades, 1990.

SOUZA, José. Galante de. Cronologia de Machado de Assis. Revista do Livro, n. 9, ano III, set. 1958.

SOUZA, Josuelene da Silva. O leitor empírico e o leitor idealizado: públicos de literatura. In: ENCONTRO NACIONAL DE PESQUISADORES DE PERIÓDICOS LITERÁRIOS, 4., 2010, Feira de Santana. Anais [...]. Feira de Santana: Uefs, 2013. Disponível em: http://www2.uefs.br/enapel/files/4enapel_anais.p169-181.pdf. Acesso em: 12/01/2019.

STAUT, Léa Mara Valesi. Machado de Assis na França. Travessia, Florianópolis, n. 16, 17, 18, p. 279-290, 1989. 


\section{NOTAS DE AUTORIA}

Milena Alves Borba (mileborba@gmail.com) é graduada em Letras pela Universidade Federal de Pelotas, UFPel. Possui pós-graduação - Lato Sensu em Língua portuguesa e Literatura em Contexto Escolar pela Universidade Paulista, UNIP. Atualmente é Mestranda em Letras do Programa de Pós-Graduação em Letras (M/D) da Universidade Federal de Pelotas - UFPel. Bolsista Capes.

Alfeu Sparemberger (berger9889@gmail.com) é graduado em Letras pela Universidade Regional do Noroeste do Estado do Rio Grande do Sul (UNIJUI). Possui mestrado em Letras pela Universidade Federal de Santa Catarina (1989) e doutorado em Letras (Estudos Comparados de literaturas de língua portuguesa) pela Universidade de São Paulo (2004). atua na área de letras, com ênfase em literatura brasileira, literaturas de língua portuguesa e sistemas literários.

\section{Como citar esse artigo de acordo com as normas da revista}

BORBA, Milena Alves; SPAREMBERGER, Alfeu. À roda da vida de Machado de Assis em "Viagens e viajantes na história da literatura". Anuário de Literatura, Florianópolis, v. 24, n. 2, p. 146-163, 2019.

\section{Contribuição de autoria}

Milena Alves Borba: Criação da ideia que originou o trabalho, elaboração do manuscrito e análise de dados e discussão dos resultados finais.

Alfeu Sparemberger: Participação no processo de concepção, elaboração do manuscrito e discussão dos resultados finais.

\section{Financiamento}

O presente trabalho foi realizado com apoio da Coordenação de Aperfeiçoamento de Pessoal de Nível Superior - Brasil (CAPES) - Código de Financiamento 001.

\section{Consentimento de uso de imagem}

Não se aplica.

\section{Aprovação de comitê de ética em pesquisa}

Não se aplica.

\section{Licença de uso}

Este artigo está licenciado sob a Licença Creative Commons CC-BY. Com essa licença você pode compartilhar, adaptar, criar para qualquer fim, desde que atribua a autoria da obra.

\section{Histórico}

Recebido em: 19/07/2019

Aprovado em: 01/10/2019

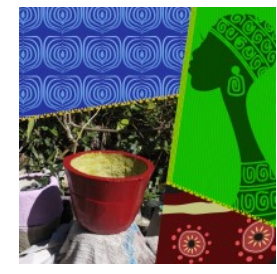

